\title{
Mutagenic Effect of Ethyl Methane Sulphonate and Sodium Azide on Pod Characters in Chickpea (Cicer arietinum L.)
}

\author{
Navnath G. Kashid \\ Department of Botany, Vasant Mahavidyalaya Kaij, Dist: Beed. Maharashtra. India. 431123.
}

\begin{abstract}
In the present investigation the different quantitative characters in M2 and M3 generations were studied to estimate the variability induced by mutagenic treatments. A through statistical analysis of the data on individual quantitative character was done to analyses the effect of mutations in shifting the mean and variance in either direction. The effect of chemical mutagens on pod characters, the productivity in terms pods per plant as compared with control/normal plants was found to be better in some of the viable mutants like tall, early maturing (in BDN 9-3) high yielding and late maturity. Elongated pod mutant was recorded only in BDN 9-3, in this mutant, the pods were found to be slightly elongated in shape as compared to control. The seeds of this mutant were larger, elongated and more weighted than the control.
\end{abstract}

Keywords: pods per plant, chemical mutagen, chickpea

\section{Introduction}

Chickpea (Cicer arietinum L.), also known as Bengal gram, Gram or Chana (Hindi), is an important ancient annual grain legume used as human diet. Chickpea is a winter (rabi) season crop and requires cool climate for its growth and high temperature for maturity. Chickpea performs well when grown on sandy, loam soils and having well drainage system.

Chickpea is the third most important pulse crop in the world but it ranks first among pulses in India. In India, chickpea is grown in the drier areas as they are best suited for its production. Chickpea seeds are utilized both unripe and cooked as vegetable. The dry seeds are used for making soups. Fried chickpea seeds are popular in many countries as a delicious treat.

Genetic enhancement for yield, synchronization, tolerance to major biotic and abiotic stresses and increasing the nutrient composition of the crop to large extent is a major concern due to less genetic variability in chickpea. Since genetic variability is a prerequisite for any successful breeding programme and creation and management of such induced variability becomes a central base for the improvement of any crop species. Creation of genetic variability followed by screening and selection of the best plants is a major target for this crop. The possibility offered by mutagenic agents to induce new genetic variation is, therefore, of extreme interest and importance. Since chickpea is a self-pollinated crop, mutation breeding could be rewarding for broadening the genetic base of total plant yield, yield contributing traits and other important traits like nutrition compositions.

Experiments on higher plants have shown that chemical mutagens, apart from easy handling and better efficiency, have much greater advantage and specificity than ionizing radiations due to a milder effect on the genetic material of a cell as against the physical mutagens which break the chromosome (Auerbach, 1965). Rapoport (1946) discovered overwhelming majority of strong chemical mutagens which are being used widely in genetic and breeding research.

\section{Material and Methods}

In the present mutation breeding programme, BDN 9-3 and PG-5 cultivars of chickpea were obtained from Agricultural Research Station Badnapur, Dist: Jalna (Maharashtra) and Mahatma Phule Krishi Vidyapeeth, Rahuri, Dist: Ahmad.Nagar (Maharashtra) India, for induction of the mutations. Mutations were induced in chickpea by using different concentrations of two chemical mutagens like $0.05 \%, 0.10 \%$ and $0.15 \%$ of Ethyl methane sulphonate (EMS) and $0.01 \%, 0.02 \%$ and $0.03 \%$ of Sodium Azide (SA). The programme of mutation breeding was spread over three generations, viz. M1, M2 and M3. Pods were counted for each plant and noted as the number of pods per plant.

Various statistical data were calculated using the following formulae;

Mean $=\Sigma \mathrm{x} / \mathrm{n}$

Variance $=\left(\sum \mathrm{x}^{2} / \mathrm{n}\right)-\mathrm{x}^{2}$

Standard deviation $(\mathrm{SD})=\sqrt{\text { Variance }}$

Standard Error $(\mathrm{SE})=\mathrm{SD} / \sqrt{\mathrm{N}}$

Coefficient of variation $(\mathrm{CV})=(\mathrm{SD} /$ Mean $) \times 100$.

Critical difference $($ C.D) $=$ S.E. $($ d $) \times$ te.d.f. (error degree of freedom)

Where S.E. $(d)=$ S.E. difference $=$ S.E. $($ mean $) \times 2$

$\mathrm{S} . \mathrm{E} .(\mathrm{m})=\mathrm{S} . \mathrm{E} .($ mean $)=$ mean error sum of square

$\sqrt{r}$

$\mathrm{r}=$ number of replication

\section{Result}

The effect of all the mutagenic treatments on pods per plants revealed negative as well as positive shift in mean values in both the cultivars of chickpea in M2 and M3 generations. In BDN $9-3,0.05 \%$ and $0.15 \%$ of EMS, where as $0.01 \%$, $0.02 \%$, and $0.03 \%$ concentrations of SA showed a 


\section{International Journal of Science and Research (IJSR) \\ ISSN (Online): 2319-7064}

Index Copernicus Value (2013): 6.14 | Impact Factor (2014): 5.611

significant negative shift in mean values in both M2 and M3 generations.

In case of PG-5 cultivar, some of the mutagenic treatments showed negative shift in mean values while others showed positive shift in mean values in M2 generations. In M3 generations a positive shift in mean values for all the mutagenic treatments could be evidently seen.

The mean values in regard to number of pods per plant in $\mathrm{M}_{2}$ generation showed negative shift at $0.05 \%$ and $0.15 \%$ EMS and $0.01 \%, 0.02 \% \& 0.03 \%$ SA treatments in variety BDN 9-3, while at $0.10 \%$ EMS treatments a positive shift in mean values could be noted. In variety PG-5 except $0.05 \%$ EMS and $0.01 \%, 0.02 \%$ SA concentrations remaining all treatments positive shift in mean values could be observed.

In $\mathrm{M}_{3}$ generation the mean values of pods per plants $0.10 \%$ concentrations of EMS positive shift in mean value observed, remaining all treatments of EMS and SA having negative shift in mean values in cultivars BDN 9-3. While in PG-5 except at $0.02 \%$, SA, all EMS and SA treatments the significant positive shift in mean values could be observed.

\section{Discussion}

A changed phenotype is the outcome of several complex steps in the process of mutation which should be then viable to be traced and recognized. Several mechanisms that could account for mutability differences have been proposed, but no evidence seems to explain the full range of the spectrum.

The elongated pod mutants in BDN 9-3 could be observed in the present programme. The variations in pod size like flat pod, long pod character have been recorded by Hakande (1992), Sonvane (2000) and Kulthe (2003) in different plants systems.

Singh and Raghuvanshi (1991) reported that positive shift in mean value for number of pods per plant due to induced mutagenisis with EMS treatment in blackgram. There were an increased number of pods per plant, number of seeds per plant in soybean as the dose of gamma rays increased. The critical dose that prevented the shoot and root elongation varied among species and also ranged from genotypes to genotype within the crop species find out that Muhammad et al., (2001) in mungbean.

Ignacimuthu and Babu (1989) reported more number of clusters per plant in blackgram due to gamma rays and Ahmed John (1993) recorded the number of pods per plant decreased in all the genotypes as the dose of irradiation increased.

Rajput (1973) The mean number of pods bearing branches and pods per plant increased simultaneously in M2 and M3 generations, suggesting close correlation between these two traits. The number of pod sets was higher in the lines which produced large number of flowers. All these three traits namely, number of pods bearing branches, number of pods per plant and number of flowers seem to be highly correlated. It has been suggested (Khan and Goyal, 2009, Wani, 2009) that an increase in the yield of pulses could be achieved by enhancing pod number.
The mean number of seeds per pod seems to be a stable character as most of the treatments with gamma rays and EMS alone or in combination did not make much difference in the mean values in both the varieties of Chickpea. This is probably due to the fact that only 1-2 seeds can be accommodated in the pod of chickpea. Kumar and Sinha (1989) in pigeon pea and Khan et al. (2005d) in mungbean recorded a non significant difference for the number of seeds per pod after mutagenic treatments.

Table 1: Effect of mutagens on number of pods per plant in M2 generation of chickpea.

Variety: BDN 9-3.

\begin{tabular}{|c|c|c|c|c|c|}
\hline Treatment & $\begin{array}{c}\text { Concentration } \\
(\%)\end{array}$ & Mean & \pm SE & $\begin{array}{c}\text { Shift in } \\
\text { mean }\end{array}$ & $\begin{array}{c}\text { Coefficient of } \\
\text { variation }\end{array}$ \\
\hline Control & - & 78.86 & 0.43 & - & 0.95 \\
\hline \multirow{3}{*}{ EMS } & 0.05 & 72.12 & 0.66 & -6.74 & 1.59 \\
& 0.10 & 83.66 & 0.72 & 4.80 & 1.49 \\
& 0.15 & 68.92 & 0.83 & -9.94 & 2.10 \\
\hline \multirow{3}{*}{ SA } & 0.01 & 67.80 & 0.54 & -11.06 & 1.40 \\
& 0.02 & 69.33 & 0.46 & -9.53 & 1.15 \\
& 0.03 & 74.96 & 0.60 & -3.90 & 1.40 \\
\hline
\end{tabular}

$\pm \mathrm{SE}=2.05 \mathrm{CD}$ at $1 \%=6.66 \mathrm{CD}$ at $5 \%=4.63$

Table 2: Effect of mutagens on number of pods per plant in M2 generation of chickpea. Variety: PG-5.

\begin{tabular}{|c|c|c|c|c|c|}
\hline Treatment & $\begin{array}{c}\text { Concentration } \\
(\%)\end{array}$ & Mean & \pm SE & $\begin{array}{c}\text { Shift in } \\
\text { mean }\end{array}$ & $\begin{array}{c}\text { Coefficient of } \\
\text { variation }\end{array}$ \\
\hline Control & - & 85.94 & 0.34 & - & 0.69 \\
\hline \multirow{3}{*}{ EMS } & 0.05 & 84.20 & 0.69 & -1.74 & 1.42 \\
& 0.10 & 87.12 & 0.63 & 1.18 & 1.26 \\
& 0.15 & 88.34 & 0.51 & 2.40 & 1.01 \\
\hline \multirow{3}{*}{ SA } & 0.01 & 83.26 & 0.46 & -2.68 & 0.96 \\
& 0.02 & 82.10 & 0.57 & -3.84 & 1.21 \\
& 0.03 & 87.18 & 0.75 & 1.24 & 1.49 \\
\hline
\end{tabular}

$\pm \mathrm{SE}=0.80 \mathrm{CD}$ at $1 \%=2.60 \mathrm{CD}$ at $5 \%=1.80$

Table 3: Effect of mutagens on number of pods per plant in M3 generation of chickpea. Variety: BDN 9-3.

\begin{tabular}{|c|c|c|c|c|c|}
\hline Treatment & $\begin{array}{c}\text { Concentration } \\
(\%)\end{array}$ & Mean & \pm SE & $\begin{array}{c}\text { Shift in } \\
\text { mean }\end{array}$ & $\begin{array}{c}\text { Coefficient } \\
\text { of variation }\end{array}$ \\
\hline Control & - & 76.12 & 0.60 & - & 1.37 \\
\hline \multirow{3}{*}{ EMS } & 0.05 & 70.18 & 0.83 & -5.94 & 2.06 \\
& 0.10 & 81.80 & 0.77 & 5.68 & 1.65 \\
& 0.15 & 69.10 & 0.80 & -7.02 & 2.02 \\
\hline \multirow{3}{*}{ SA } & 0.01 & 68.18 & 0.69 & -7.94 & 1.76 \\
& 0.02 & 71.92 & 0.75 & -4.20 & 1.80 \\
& 0.03 & 75.86 & 0.72 & -0.26 & 1.64 \\
\hline
\end{tabular}

$\pm \mathrm{SE}=1.70 \mathrm{CD}$ at $1 \%=5.52 \mathrm{CD}$ at $5 \%=3.84$

Table 4: Effect of mutagens on number of pods per plant in M3 generation of chickpea. Variety: PG-5.

\begin{tabular}{|c|c|c|c|c|c|}
\hline Treatment & $\begin{array}{c}\text { Concentration } \\
(\%)\end{array}$ & Mean & \pm SE & $\begin{array}{c}\text { Shift in } \\
\text { mean }\end{array}$ & $\begin{array}{c}\text { Coefficient } \\
\text { of variation }\end{array}$ \\
\hline Control & - & 83.18 & 0.69 & - & 1.44 \\
\hline \multirow{3}{*}{ EMS } & 0.05 & 83.94 & 0.34 & 0.76 & 0.71 \\
& 0.10 & 86.18 & 0.46 & 3.00 & 0.92 \\
& 0.15 & 89.26 & 0.23 & 6.08 & 0.44 \\
\hline \multirow{3}{*}{ SA } & 0.01 & 83.80 & 0.63 & 0.62 & 1.31 \\
& 0.02 & 81.96 & 0.75 & -1.22 & 1.58 \\
& 0.03 & 88.16 & 0.80 & 4.98 & 1.58 \\
\hline
\end{tabular}

$\pm \mathrm{SE}=0.94 \mathrm{CD}$ at $1 \%=3.05 \mathrm{CD}$ at $5 \%=2.12$ 


\section{References}

[1] Auerbach C. (1965): Drosophila melanogaster, New mutants chemically induced mutants and rearrangements. Dros. Int. Serv. 17: 48-50.

[2] Ahmad S. (1993). Meiotic studies in two cultivars of Cicer arietinum L. after gamma irradiation. Cytologia. 58: 61-65.

[3] Hakande T. P. (1992): Cytogenetical studies in Psophocarpous tetragonolobous (L.) DC. Ph. D. Thesis, Marathwada University, Aurangabad, India.

[4] Khan S. and Goyal S. (2009). Improvement of mungbean variety through induced mutations. African J. Plant Sci. 3: 174-180.

[5] Ignacimuthu S \& Babu C R (1989). Induced variation in protein quantity and quality in the wild and cultivated urd mungbeans. Indian. J. Genet. 49: 173-181.

[6] Khan Samiullah, Mohd Rafiq Wani and Kouser Parveen (2005). An Induced Bushy Mutant in Mungbean; Mutation Breeding Newsletter and Review, No.1, June 2005.

[7] Kulthe M.P. (2003): Induced mutational and biochemical studies in winged bean ( psophophocarpous tetragnlobus L. DC.). Ph.D. Thesis Dr. Babasaheb Ambedkar Marathwada University Aurangabad.

[8] Kumar P. and Sinha S.S.N. (1989a); Effect of gamma radiation on plant attributes in two cultivars of Cajanus cajan and two species of Moghania; Legume Res., 12(3): 115-122. Chapter-7. References Page 160

[9] Kumar P. and Sinha, S.S.N. (1989b.); Gamma rays induced meiotic abnormalities in two cultivars if Cajanus cajan and two species of Moghanoa; Indian J. Forestry, 12(2): 122-131.

[10] Muhammad Yaqoob and Abdur Rashid (2001); Induced mutation studies in some Mungbean cultivars; Pak. J. Bio. Sci., 1(9): 805-808.

[11] Rapoport I. A. (1946): Carbonly compounds and the chemical mechanism of mutation O. R. (Doklady) Acad. Sci., USSR, 54: 65-67.

[12] Rajput M.A. (1973); Gamma irradiated studies in mungbean; Pak J. Scientific Res. 25: 167-172.

[13] Singh R.H. and Raghuvanshi S.S. (1991); Bold seeded mutant in Blackgram; Mut.Breed. Newsletter, 38: $5-6$.

[14] Sonavane A.S. (2000): Genetic improvement of winged bean through mutation breeding $\mathrm{Ph}$. D. Thesis Dr. Babasaheb Ambedkar Marathawada University, Aurangabad.

[15] Wani A.A. (2009). Mutagenic effectiveness and efficiency of gamma Rays, ethyl methane sulphonate and their combination treatments in chickpea (Cicer arietinum L.). Asian J. of Plant Sci. 8(4): 318-321. 